\title{
Savcılıebeyit (Kaman-Kırșehir) Gold Mineralization and Its Genetic Relationship With Post-Collisional Exhumation and Extensional Tectonics in Central Anatolia, Turkey
}

\author{
Savcılıebeyit (Kaman-Kırșehir) Altın Cevherleșmesi ve Cevherleșmenin \\ Orta Anadolu'nun (Türkiye) Çarpıșma Sonrası Yükselme ve Genleșme \\ Tektoniği ile Olan Kökensel Ilișkisi
}

\author{
YURDAL GENÇ ${ }^{\star 1}$, M.TEKIN YÜRÜR ${ }^{1}$ \\ "Hacettepe University, Department of Geological Engineering, 06800 Beytepe, Ankara, Turkey \\ Geliș (received) : 03 Eylül (September) 2018 \\ Kabul (accepted) : 24 Kasım (November) 2018
}

\begin{abstract}
Gold exploration works in central Anatolia, Turkey, were intensified during the last decade, and potentially important gold mineralizations were discovered. In the region, important gold discoveries hosted by metamorphic and granitic rocks are, in the west, Savcılıebeyit and Terziali (Kırșehir), in the middle part, Himmetdede and Mahmatlar (Kayseri), Akçataș (Nevșehir), and at the southeast, Gümüșler (Niğde) mineralizations. The Savcılı gold mineralization consists mainly of gold-quartz veins, and is the first discovered gold enrichment hosted by metamorphic rocks of west-central Anatolia. These veins are situated at the southeastern margin of the Cefalıkdağ-Baranadağ granite-migmatite dome, at $60 \mathrm{~km}$ west of the city of Kırșehir. In this study, preliminary results of geological and structural investigations of the gold-quartz veins are presented.

The study area is part of the Palaeozoic-Mesozoic Kırșehir Massif that comprises mainly high-grade metamorphic and plutonic rocks covered by Cenozoic sediments. The gold-quartz veins are hosted by migmatite, migmatitic gneiss, gneiss-schist-marble intercalations, calc-silicate gneiss and marble. Quartz veins are discordant with respect to the foliation and major lithologic boundaries, and have sharp contacts with the enclosing metamorphic wall rocks. Veins occur as single or composite, relatively continuous veins that are up to about $2 \mathrm{~km}$ long and extend for at least $200 \mathrm{~m}$ down dip. Their thickness ranges from a few millimetres to two metres.

The gold-quartz veins consist mainly of quartz, arsenopyrite, pyrite and secondary haematite and limonite. Other common minerals in the veins are calcite, muscovite, biotite, chlorite and epidote. The distribution of gold is erratic, and only weathered, haematite- and limonite-rich parts of the veins near the surface consistently display higher gold contents.

Homogenisation temperatures obtained from fluid inclusions in the quartz vein have a wide range, from $160^{\circ} \mathrm{C}$ to well above $400^{\circ} \mathrm{C}$. The fluid inclusions are generally rich in carbon dioxide and also have high salinities $(20-33 \% \mathrm{NaCl}$ equivalent).

The gold-quartz veins have many similarities to orogenic gold deposits in terms of metal associations, wall-rock alteration assemblages, mineralogy, formation conditions and structural control. The spatial association of the veins with migmatites, high-grade metamorphic rocks and granitoids suggests an origin related to metamorphism, uplift and/or migmatite doming and granitoid emplacement in central Anatolia.
\end{abstract}

Keywords: Granitoid-migmatite doming, Kırșehir Massif, orogenic gold deposit, Turkey.

Öz

Orta Anadolu'da altın aramaları son on yılda artmıș ve önemli potansiyel altın cevherleșmeleri keșfedilmiștir. Bölgede, metamorfik ve granitik kayaçlar içinde önemli altın bulguları batıda Savcılıebeyit ve Terziali (Kırșehir), orta kesimlerde Himmetdede ve Mahmatlar (Kayseri), Akçataș (Nevșehir), ve güneydoğuda Gümüșler (Niğde) cevherleșmeleridir. Savcılıebeyit altın cevherleșmesi daha çok altınlı kuvars damarlarında görülmekte ve Orta-Batı Anadolu'da metamorfik kayaçlar içinde keșfedilen ilk altın zenginleșmesidir. Bu damarlar Kırșehir'in 60 km batısındaki Cefalıkdağ-Baranadağ granit-migmatit domunun güneydoğu eteklerinde bulunmaktadırlar. Bu çalıșmada bu altınlı kuvars damarlarının jeolojik ve yapısal ön çalıșmaları sunulmuștur

\footnotetext{
* Y. Genç

e-posta: ygenc@hacettepe.edu.tr
} 
Inceleme alanı, Senozoyik çökellerle örtülü ve çoğunlukla yüksek dereceli metamorfik ve derinlik kayaçlarının yeraldı̆̆ı Paleozoyik-Mezozoyik Kırșehir Masifi içinde yer almaktadır. Altınlı kuvars damarları migmatitler, migmatitik gnayslar, gnays-șist-mermer ardalanmaları, kalk-silikatik gnayslar ve mermerler içinde bulunmaktadırlar. Kuvars damarları metamorfik yan kayaçların yapraklanma ve önemli litolojik düzlemleriye uyumsuz olup damarların yankayaçlarla dokanakları keskindir. Damarlar, tek veya damar sistemleri șeklinde gözlenmekte olup, devamlılıları doğrultu yönünde 2 km ye, eğim yönünde ise en az $200 \mathrm{~m}$ ye ulașmaktadır. Damar kalınlıkları birkaç mm den 2 metreye kadar değișmektedir.

Altınlı kuvars damarları bașlıca kuvars, arsenopirit, pirit ve ikincil hematit ve limonitten olușmaktadır. Diğer yaygın mineraller kalsit, muskovit, biyotit, klorit ve epidottur. Damarlar içinde altının dağılımı düzensiz olup damarların sadece oksitlenmiș, hematit ve limonitçe zengin yüzeye yakın kesimlerinde yüksek altın değerleri elde edilmektedir..

Kuvars damarlardaki sıvı kapanımlarının homojenleșme sıcaklıkları $160^{\circ}$ C'den $400^{\circ}$ C'nin üzerinde geniș bir aralıkta dağılım göstermektedir. Sıvı kapanımları genelde karbon dioksitçe zengin olup yüksek tuz içeriklidirler (\% 20-33 NaCl eșdeğeri).

Altınlı kuvars damarları, metal içeriği, yan kayaç alterasyonu, mineraloji, olușum koșulları ve yapısal kontrol açısından orojenik altın yatakları ile benzer özelliklere sahiptir. Damarların migmatitlerle, yüksek dereceli metamorfik kayaçlar ve granitoidlerle olan mekânsal birlikteliği bunların olușumunun Orta Anadolu'daki metamorfizma, yükselme ve/veya migmatitik domlașma ve granitoid yerleșimi ile ilgili olduğunu ifade etmektedir.

Anahtar Kelimeler: Granitoid-migmatit domlașması, Kırșehir Masifi, orojenik altın yatağı, Türkiye.

\section{INTRODUCTION}

Although central Anatolia has historically been recognised for hosting significant lead-zinc, iron, molybdenum-copper, fluorite and antimony deposits, gold exploration has only intensified during the last decade, resulting in the discovery of a few potentially important gold-ore bodies (Savcılıebeyit and Çayağzı (Terziali)-Kırșehir; Mahmatlar-, and HimmetdedeKayseri, Akçataș-Nevșehir and Gümüșler-Niğde) (Fig. 1). Some previous studies have established the existence of gold in this region. Özcan and Çağatay (1989) reported scheelite mineralisation associated with quartz veins within silicified metamorphic rocks of the Kırșehir region. Genç et al. (2003) and Coșkun Delibaș and Genç (2004) described saprolitic gold enrichments in the same region. Moreover, gold grains have been found in some stream sediments derived from metamorphic rocks of the massif (H.Türkmen, pers. comm. 2004).

In the Gümüșler and Çamardı areas of the Niğde Province, Pehlivan and Alpan (1986) found gold, cinnabar, and scheelite grains in stream sediments and identified several anomalous locations for gold, mercury and scheelite. In the same region, Akçay (1994) reported near-surface gold enrichment zones (up to 37 ppm) in Sb-Hg-W-bearing quartz veins.

Gold-quartz veins (GQVs) near Savcılıebeyit village, $60 \mathrm{~km}$ west of Kırșehir, are the first discovered gold occurrences hosted by metamorphic rocks in west- central Anatolia (Fig. 1). They were found in 1999 as a result of systematic exploration carried out in central Anatolia by MTA (Mineral Research and Exploration Institute). Gold anomalies were detected through a programme of stream-sediment, soil and hard-rock geochemical studies facilitated by trenching and $670 \mathrm{~m}$ of drilling. There is no sign of ancient goldmining activities at the site. However, the Kırșehir region does have important vein-type fluorite deposits hosted by granitoids (Bayındır, Akçakent, Pöhrenk, etc.) (Genç et al. 2003a).

The first studies on these GQVs were undertaken by Genç and Türkmen (2002) and Genç (2004). In these studies, GQVs were classified as mesothermal and orogenic gold deposits. However, their modes of formation are still not well understood. According to Groves et al. (1998), orogenic gold deposits form during compressional to transpressional deformation processes at convergent plate margins in accretionary or collisional orogens. Central Anatolia is part of the Alpine-Himalayan collisional belt and located within the convergence zone between the Eurasian and Afro-Arabian plates, and GQVs formation may therefore be attributed to the regional compressional tectonic regime. Recently, Genç and Yürür (2010) proposed that an extensional tectonic regime took place after the Late Cretaceous convergence in the region. This is why geological outlines that may be derived from the study of gold mineralizations would be useful to better understand the regional 


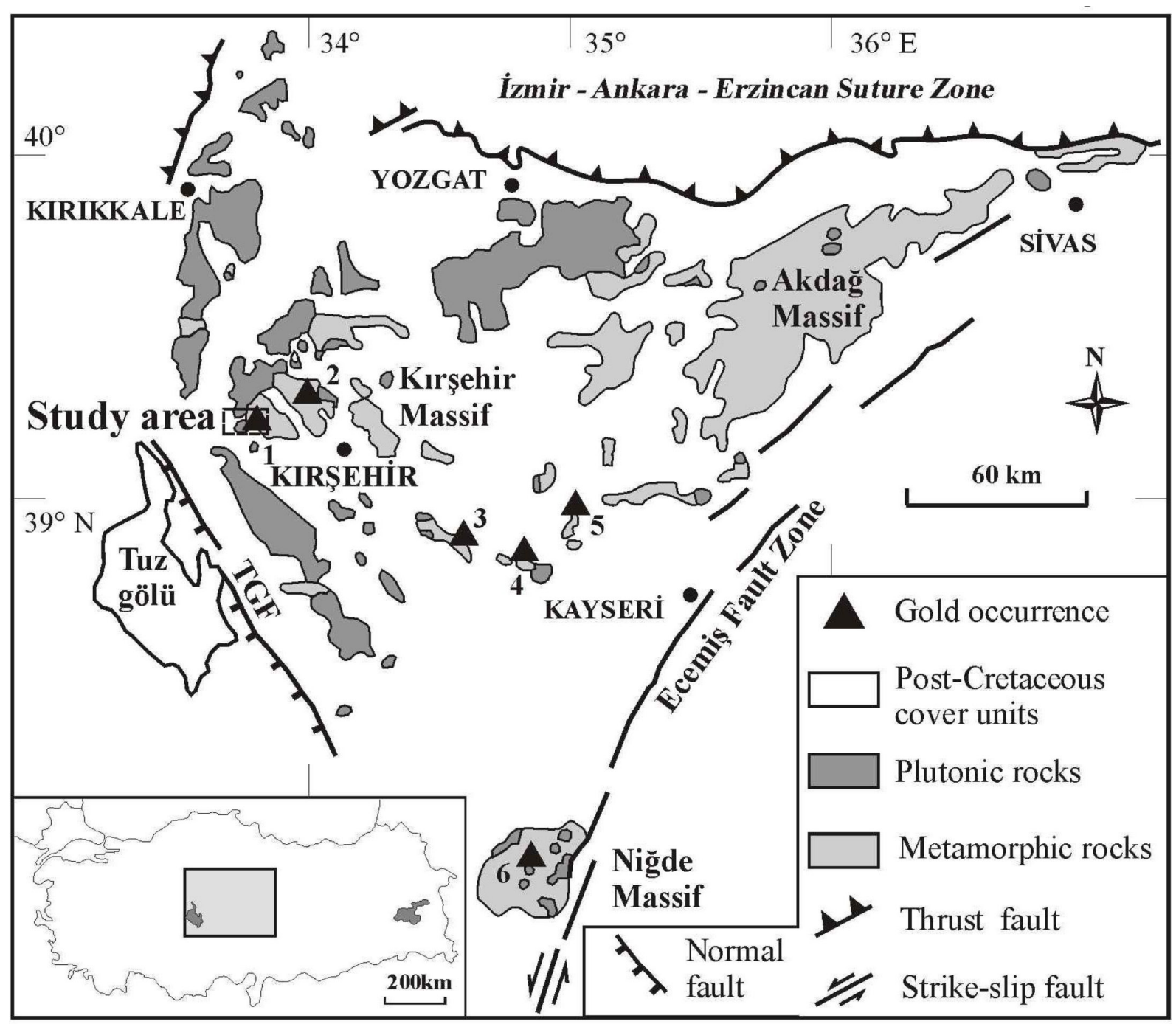

Figure 1.Simplified geological map of the central Anatolian massifs, showing the main lithological units and firstorder fault zones (modified from the 1:500.000-scale geological map (Ankara sheet) of Turkey, MTA, 2002) and gold mineralizations. TGF: Tuz Gölü Fault. Gold mineralizations: 1: Savcılıebeyit , 2: Terziali, 3 : Akçataș, 4: Mahmatlar, 5: Himmetdede and 6: Gümüșler.

Șekil 1. Ana litolojik birimleri ve önemli fay zonlarını (MTA, 2002 1:500.000 ölçekli Türkiye jeoloji haritası, Ankara paftasından değiștirilerek) ve altın cevherleșmelerinin konumlarını gösteren Orta Anadolu masiflerinin sadeleștirilmiș jeoloji haritası. TGF: Tuzgölü Fayı. Altın cevherleșmeleri: 1: Savcılıebeyit ; 2: Terziali; 3: Akçataș; 4: Mahmatlar; 5: Himmetdede ve 6: Gümüșler.

geological evolution and the relationship between mineralization processes.

The present study aims a) to give the preliminary results of studies carried out to date and to identify geologic and tectonic processes that may have controlled and influenced the development of the gold-quartz veins in central Anatolia, b) to determine the timing of vein formation, and c) to ascertain the physical and chemical conditions of vein formation. The results of this study provide a basis for further studies in central Anatolia and intend to develop a better understanding of the geologic and tectonic parameters of the environment of gold-quartz vein formation.

\section{Geology}

In central Anatolia, magmatic, metamorphic and ophiolitic rock assemblages are together termed the Central Anatolian Massif, Kırșehir Massif, Kızılırmak 
Massif or Central Anatolian Crystalline Complex (Ketin 1955; Seymen 1982; Tolluoğlu 1986; Göncüoğlu et al. 1991). The Central Anatolian Massif is bounded by the Izmir-Ankara-Erzincan suture zone to the north, the Ecemiș fault zone to the east, and the Tuz Gölü fault to the southwest (Fig. 1). The massif consists of three submassifs, namely the Kırșehir, Akdağ and Niğde (Fig. 1).

The oldest rock units in the Kırșehir submassif are metamorphic rocks which comprise mainly migmatite, gneiss, schist and marble. The stratigraphically lowest unit mainly contains the highest-grade rocks: amphibolite-interlayered migmatites, migmatitic gneisses, alternations of calc-silicate gneisses, schists, and marbles. This basal unit is unconformably overlain by lower-grade (amphibolite-facies) mica schists with marble, amphibolite, calc-silicate gneiss and quartzite intercalations. These metamorphic rocks grade upward into the lowest-grade (greenschist- to amphibolite-facies) rocks dominated by marble with mica and amphibole-schist intercalations. Silurian-Devonian and Carboniferous-Permian depositional ages for the basal and upper parts of the Kırșehir Massif, respectively, were proposed by Genç (2003).

Conflicting ages are given in the literature for the metamorphism of the massif. Older studies suggested a polyphased metamorphic history with ages ranging from Early Palaeozoic to Late Mesozoic (Pollak 1958; Brinkmann 1971 and 1976). However, any traces of pre-Alpine movements in central Anatolia cannot be observed (Ketin 1966; Erkan 1976; Seymen 1984; Whitney et al. 2001). New petrogenic and radiometric data obtained from metamorphic and plutonic rocks of central Anatolia indicate a singlephase, Late Cretaceous regional metamorphism related to crustal thickening, and a later high-temperature overprint associated with magmatism, uplift and exhumation (Erkan and Ataman 1981; Seymen 1982; Whitney and Dilek 1998; Whitney et al. 2001). In comparison to moderate $\mathrm{P}$ - high $\mathrm{T}$ regional metamorphic rocks, the low $\mathrm{P}$ - high $\mathrm{T}$ - overprinted metamorphic areas occupy relatively restricted zones, typically with a granitic or gneissic core (Göncüoğlu 1986; Erkan 1980; Özer and Göncüoğlu 1983; Tülümen 1980; Whitney and Dilek 1998).

Metamorphic rocks of the massif are characterised by clockwise P-T paths at moderate P-high T (6-7 kbar and $\left.750^{\circ} \mathrm{C}\right)$ with local low P-high T (3-5 kbar and $700-800{ }^{\circ} \mathrm{C}$ ) overprinting (Erkan 1976; Seymen 1984 and Whitney et al. 2001). For peak regional metamorphic conditions in central Anatolia, Whitney et al. (2003) gave an age interval of 85-92 Ma (U$\mathrm{Pb}$ SHRIMP) (Santonian-Turonian; Late Cretaceous, ICS, 2004). K-Ar cooling ages of biotite and amphiboles from gneiss and schists indicate a Late Cretaceous (Maastrichtian-Campanian) (69-74 Ma in the Kırșehir region, 74-81 Ma in the Niğde region) age for the overprinting low $\mathrm{P}$ - high T- metamorphism. These ages are interpreted to indicate an emplacement or cooling age of igneous rocks injected into regional metamorphites, and also the cooling age of the metamorphic sequences (Erkan and Ataman 1981; Göncüoğlu 1986; Whitney et al. 2003).

The metamorphic rocks are intruded by granitoid and syenitoids with radiometric ages ranging from $79.5 \pm 1.7$ to $39.2 \pm 1.2 \mathrm{Ma}$ (total $\mathrm{Pb}, \mathrm{Ar} / \mathrm{Ar}, \mathrm{Rb}-\mathrm{Sr}$ and apatite fission track ages) (Ayan 1963; Ataman 1972; Erkan and Ataman 1981; Whitney et al. 2001; Kadıoğlu et al. 2003; ilbbeyli et al. 2004).

The metamorphic rocks are overlain by an Upper Cretaceous, unmetamorphosed volcano-sedimentary series of diabase, basalt, radiolarian chert, pelagic limestone, shale and serpentinite (Seymen 1982), and the two units are separated by the Kaman detachment fault. A sedimentary sequence of Lutetian age nonconformably overlies the metamorphic basement rocks, Upper Cretaceous series and granitoids of the Kırșehir Massif.

\section{Savcılıebeyit Area}

The Savciliebeyit area is at the southeastern flank of the Cefalıkdağ-Baranadağ granitoid-migmatite domal structure (Fig. 2). The long axis of the dome trends NE-SW, and dome dimensions are $\sim 10 \mathrm{~km}$ $\mathrm{NE}-\mathrm{SW}$ by $\sim 5 \mathrm{~km} \mathrm{NW}-\mathrm{SE}$. Although the eastern margin of the dome is transitional with metamorphic rocks, its western margin is defined by detachment faults. The dome is asymmetrical, with the apex located on the eastern side of the structure. The granite-migmatite dome and surrounding metamorphic rocks are described by Genç (2004) as the Kırșehir Metamorphic Core Complex. The granitic core of the dome comprises monzonite, monzodiorite and granite. These rocks are coarse-grained and contain feldspar megacrysts up to $10 \mathrm{~cm}$ in length (Geven 1992; Aydın and Önen 1999; İlbeyli et al. 2004). The youngest magmatic phases are represented by 


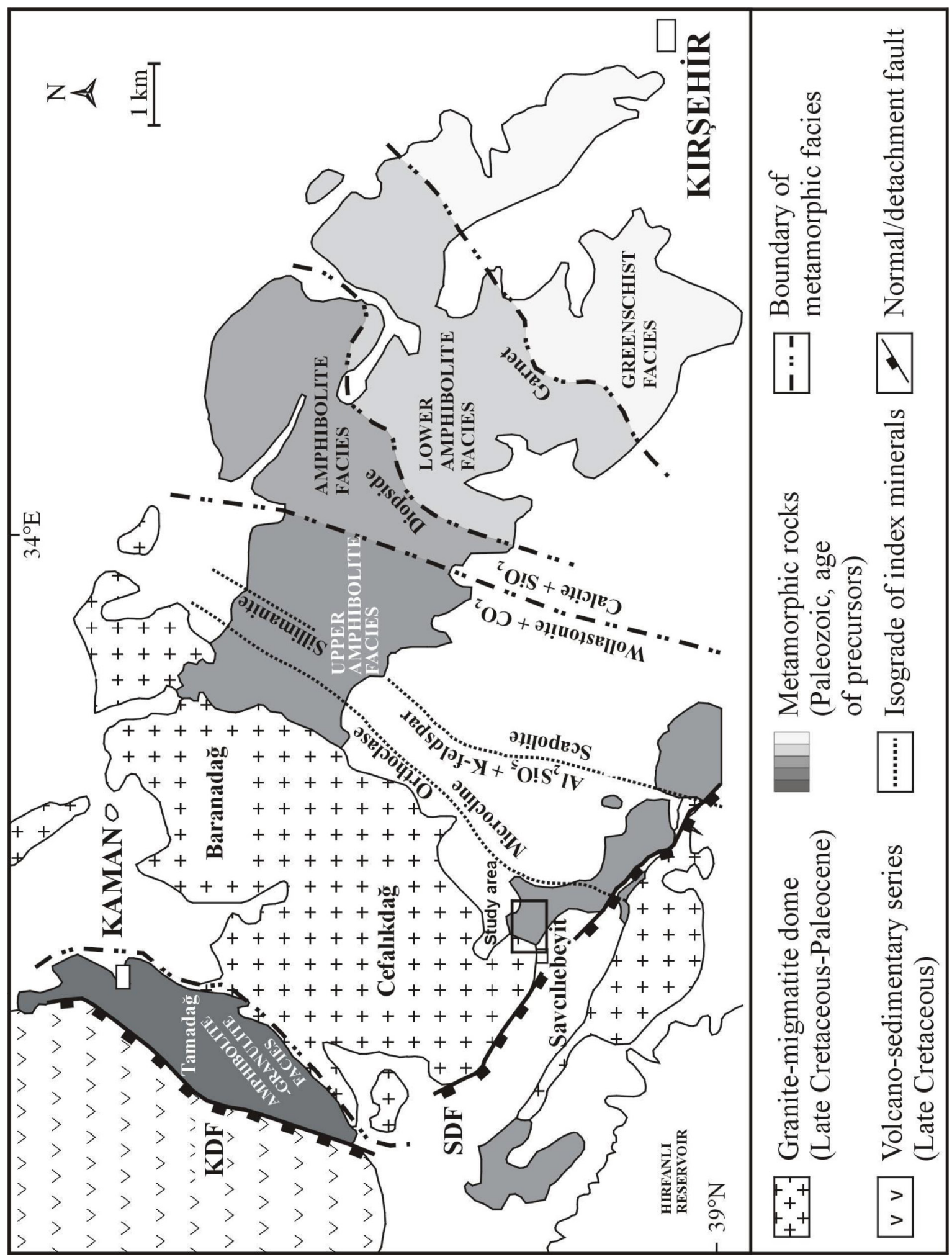

Figure 2. Geological map of the Kırșehir-Kaman region showing isograds in metamorphic rocks surrounding the Cefalıkdağ-Baranadağ granite-migmatite dome (isograd locations modified from Seymen 1981, Seymen 2000, Tolluoğlu 1986, and Whitney et al. 2001).

Șekil 2. Cefalıkdağ-Baranadağ granit-migmatit domu etrafındaki metamorfik kayaçların izogradlarını gösteren Kırșehir-Kaman bölgesi jeooloji haritası (izograd yerleri Seymen, 1981, Seymen 2000, Tolluoğlu 1986 ve Whitney vd. 2001'den düzenlenmiștir). 
microgranite stocks and aplitic-pegmatitic dykes that cut the monzonitic and granitic rocks of the older phases. 40 and $47 \mathrm{Ma}$ apatite fission-track ages for these intrusives are reported by Fayon et al. (1999). In the Tamadağ area (Fig. 2), metamorphic rocks are preserved in the northwestern part of the dome roof and are intruded by aplite dykes. At the contacts, they are slightly contact metamorphosed.

Around Savclilebeyit village, the transitional granitic core-metamorphite contacts dip moderately (40-50) to the northwest and are defined by a narrow zone of steeper foliations and closely spaced orthoclase, microcline, sillimanite and scapolite isograds. These isograds parallel the core-envelope contact in the east. In the Savclliebeyit area, lithologic layering and metamorphic stratigraphy are overturned, with younging directions facing mainly to the east and southeast. In normal, primary metamorphic stratigraphy, from bottom to top, the metamorphic rocks in the area consist of migmatite, migmatitic gneiss, a gneiss-schist-marble intercalation, quartzite, calcsilicate gneiss and marble (Fig. 3).

Migmatites are located in the western part of the area and have transitional contacts with the graniticmonzonitic core of the migmatite dome outside of the map area (Fig. 4). From core in the west to the east, and in the opposite sense of the dip direction of the lithological contacts, there is a gradational and conformable change from diatexitic migmatite, through metatexitic migmatite and migmatitic gneiss, and then to gneiss and schist.

The diatexite migmatite unit has a granitic appearance and corresponds to the hornblende granite of Geven (1992). This unit is dominated by a granitic matrix and contains enclaves of disrupted refractory layers and blocks of amphibolite, marble and metatexite (Fig. 5A). In the diatexite, pre-migmatisation structures are not preserved, but there is a well-developed flow banding.

The metatexite migmatite unit consists of dark green-grey, fine-grained layered host containing premigmatisation structures such as layering, banding and foliation (Fig. 5B, C and D). The majority of leucosomes parallel these structures. A gneiss-schistmarble intercalation overlies the migmatite unit, and mainly comprises mica gneiss, mica schist, amphibole schist, calc-schist and marble (Fig. 3). It locally contains small (15-20 m long) pockets of lensoidal pegmatite, tourmaline pegmatite and leucogranite.
The calc-silicate gneiss unit covers the gneissschist-marble intercalation along a transitional contact, and consists mainly of calcite, wollastonite, diopside and garnet. A 5-10 m thick, characteristically deep brown-grey quartzite layer is stratigraphically between the calc-silicate gneiss and gneiss-schistmarble intercalation (Fig. 3). The calc-silicate gneiss unit grades into white marble at the top of the sequence (Fig. 3).

All units have undergone regional metamorphism to varying degrees, from greenschist-amphibolite to granulite facies (Erkan 1976; Tolluoğlu and Erkan 1989; Seymen 2000; Whitney et al. 2001). Metamorphic-mineral parageneses reveal steep metamorphic gradients away from the granite, through the granulite-grade cordierite-sillimanite-bearing core, into amphibolite- and greenschist-facies rocks towards the southeastern flank of the dome (Fig. 2) (Seymen 1982; Tolluoğlu 1986; Whitney et al. 2001).

The dominant structural feature of the metamorphic rocks is folding. Seymen (1981) distinguished four folding and one brittle deformation phases in these metamorphic rocks. According to Seymen (1981), ductile deformation was followed by a brittle stage indicating uplift to higher levels. Whitney et al. (2003) reported a minimum age of $69 \mathrm{Ma}$ for fabric-forming deformation in metamorphic rocks of the Niğde region. Other significant structural features are the NW-SE-trending Savcll and NE-SW-trending Kaman detachment faults (Fig. 2). The Savcll detachment fault lies in the southern part of the dome and the Kaman detachment fault, which limits the dome to the west, is between the dome and Upper Cretaceous volcano-sediments. Whilst the Kaman fault must be older and active during the late stages of doming, the Savcll fault was active after dome emplacement, during Oligocene-Pliocene time (Genç and Yürür 2004).

\section{Gold-Quartz Veins}

Quartz veining occurs in two main types: barren pegmatitic quartz veins and gold-quartz veins. Barren pegmatitic quartz veins are characterised by pegmatitic texture and comprise mainly K-feldspar and massive quartz (Fig. 6A); they occur near the granite core, within the migmatites, and have a NE-SW orientation generally parallel to the aplite dykes (Figure 4).

The gold-quartz veins are hosted by migmatite, migmatitic gneiss, the gneiss-schist-marble intercalation, 


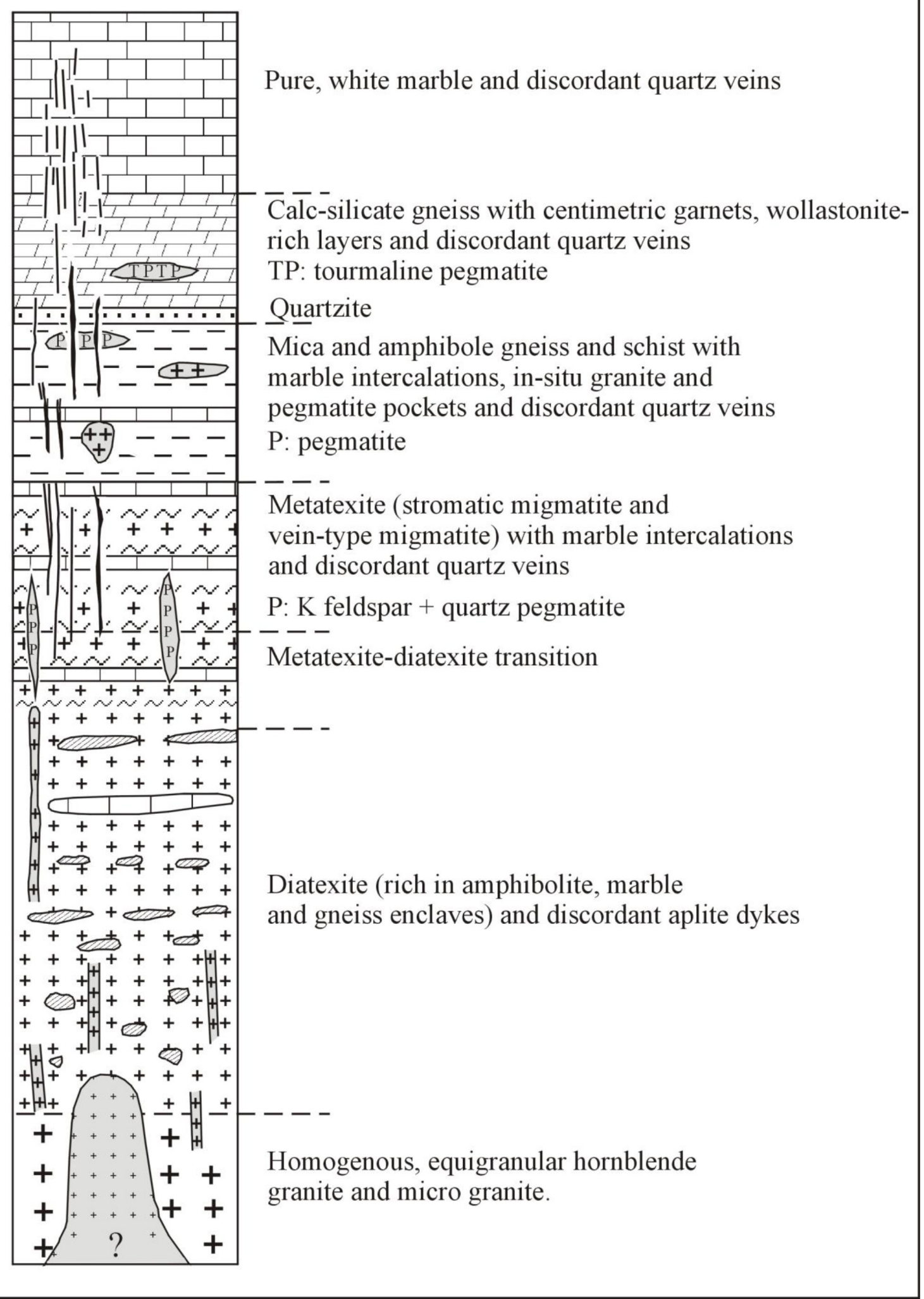

Figure 3. Schematic vertical section through the metamorphic-magmatic sequence around Savcliebeyit (not to scale).

Șekil 3. Savcılıebeyit yakınlarındaki metamorfik-magmatik birimlerin ilișkilerini gösteren șematik dikme kesit (ölçeksiz). 


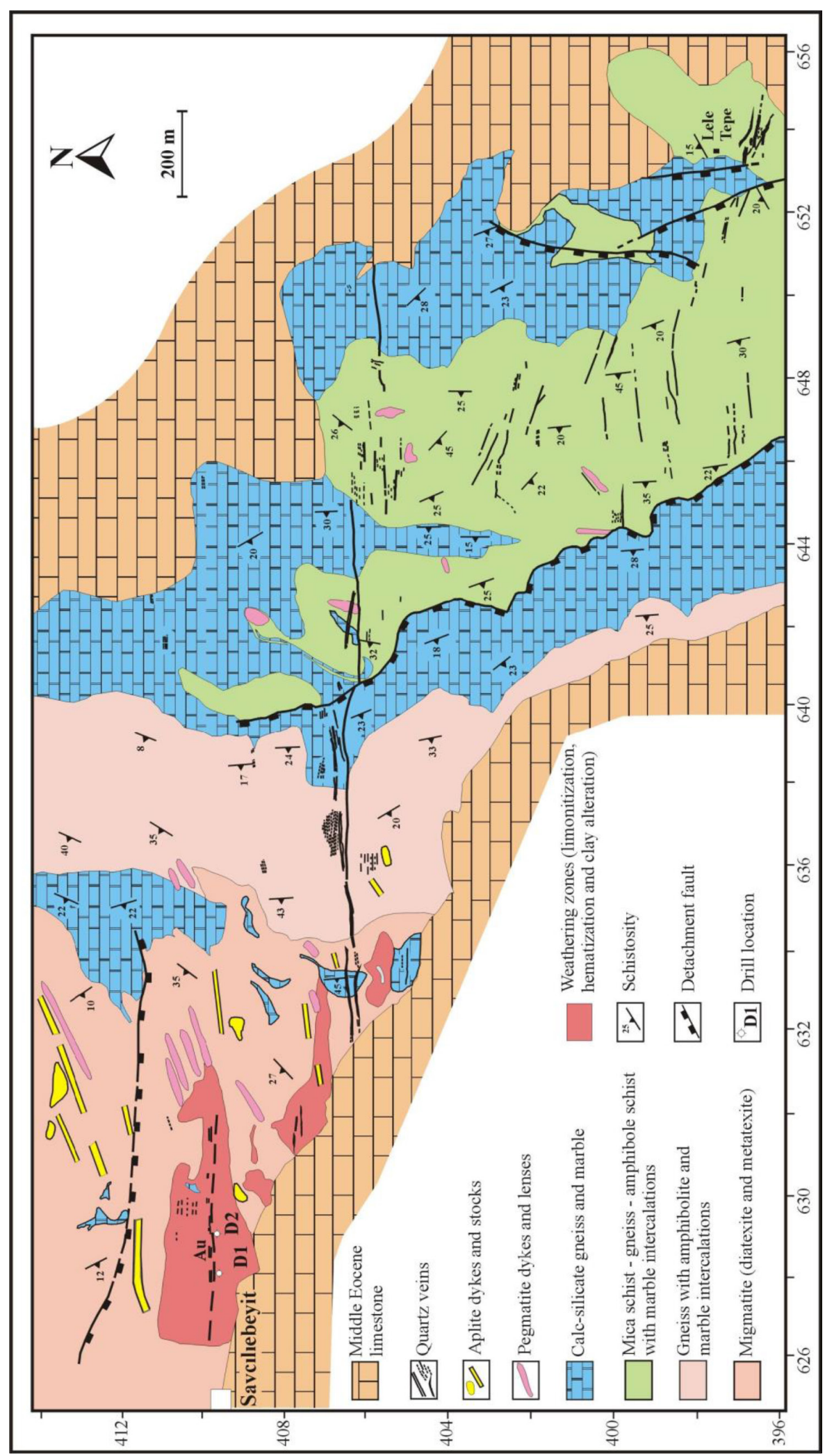

Figure 4. Geological map of the Savcllebeyit district showing the location of gold-quartz veins (modified from Türkmen et al. 2000, unpublished data).

Șekil 4. Savcllıebeyit yöresi altınlı kuvars damarlarının konumunu gösteren jeolojik harita (yayımlanmamıș Türkmen vd. 2000'den düzenlenmiștir). 

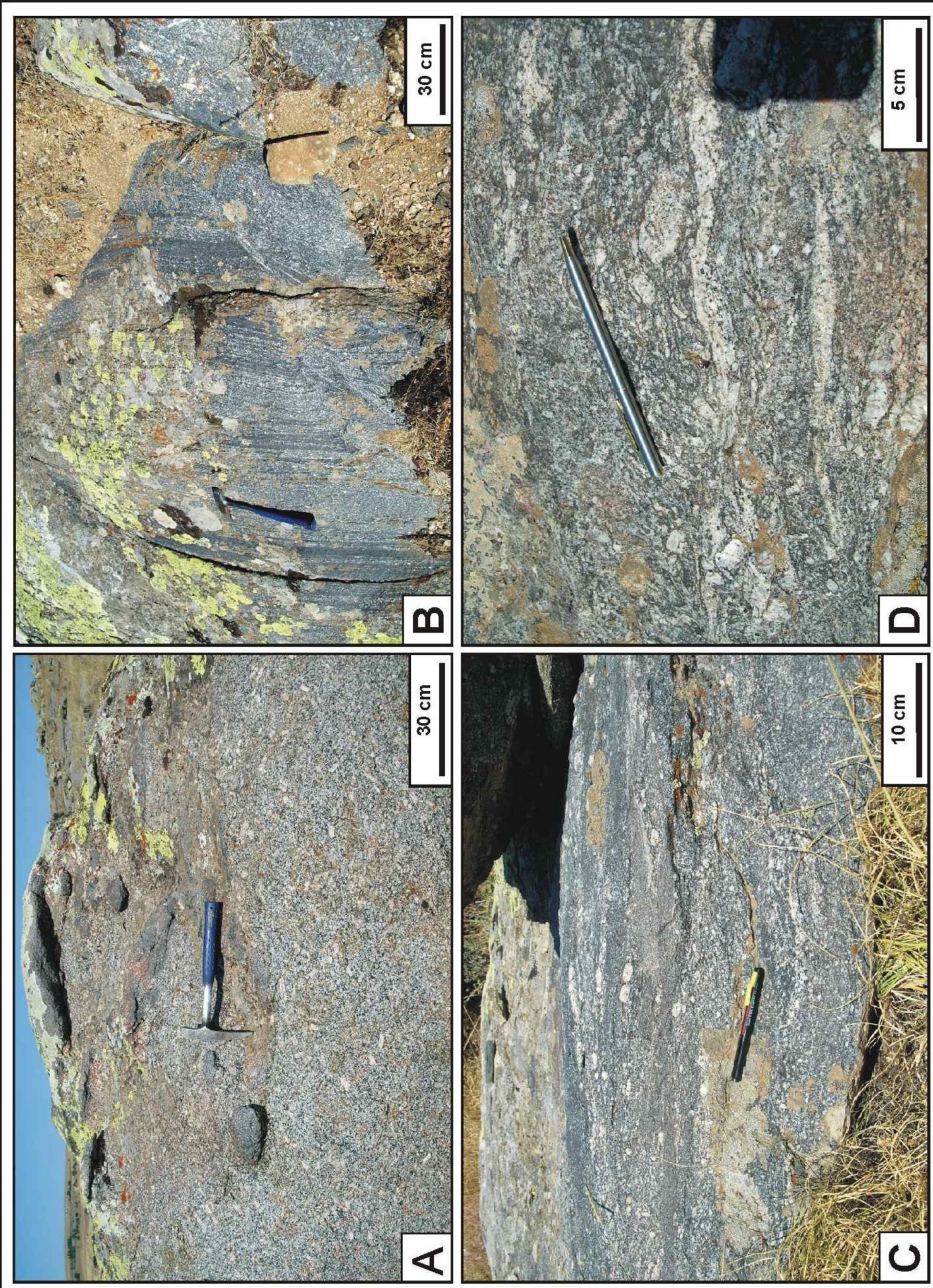

Figure 5. Migmatites in outcrop. A) Diatexitic migmatite with oriented amphibolite enclaves; B) Stromatic migmatite; C) Metatexitic migmatite with remnants of an amphibolite layer; D) Metatexite-diatexite transition. Disturbed layered leucosomes and oriented K-feldspar megacrysts within a diatexitic matrix. The photographs are from the western part of Üç Tepe.

Șekil 5. Migmatit mostraları. A) Diateksitik migmatitlerde yönlenmiș amfibolit anklavları; B) Stromatik migmatit; C) Metateksitik migmatit içinde amfibolit kalıntıları; D) Metateksit-diyateksit geçiși. Diyateksitik hamur içinde ilksel șekilleri bozulmuș tabakalı lökosomlar ve yönlenmiș K-feldspat megakristalleri. 
calc-silicate gneiss and marble (Fig. 4), and have a general E-W orientation. Vein systems consist mainly of a well-defined set of closely spaced, subparallel and structurally related veins that are individually discontinuous and have variable widths (Fig.4, Fig.6B, $\mathrm{C}, \mathrm{D}$ and $\mathrm{E})$. The quartz veins are discordant with respect to the foliation and major lithologic boundaries, and have sharp contacts with the enclosing metamorphic wall rocks (Fig.4, Fig.6G, $\mathrm{H}$ and I). In the deeper parts of the system, as seen in the drill core, some quartz veins parallel foliation surfaces (Fig. 7). Although the thickness of the veins ranges from a few millimetres to two metres, and up to hundreds of metres in length, most of the quartz veins are less than $15 \mathrm{~cm}$ wide and continuous for only a few metres. The longest quartz veins made up of massive white quartz are on the decimetre to metre scale, with minor brecciation and calcite enrichment at vein margins. The general strike of the subvertical goldquartz veins is E-W (Fig. 4). They have been detected down to depths $>200 \mathrm{~m}$. Adjacent to the quartz veins, the host rocks commonly display metasomatic effects (Fig. 7). Between the distant individual quartz veins, the metamorphic rocks rarely show visible evidence of alteration. Simple quartz veins are well developed in the mica schist, whereas subparallel vein sets are observed in the marble. The subparallel veins commonly occur in zones up to $40 \mathrm{~m}$ wide. The vein quartz is generally massive (Fig. $6 \mathrm{D}$ and F), clear white to dark grey and coarse grained. Banded and breccia textures are abundant (Fig. 6C) and, in some quartz veins, a fibrous structure is also widespread. Breccia and stockwork textures in veins indicate very low temperature and pressure conditions. According to McCuaig and Kerric (1994), banded veins indicate that hydrothermal fluids responsible for vein formation were approximately at lithostatic pressures and underwent transient sublithostatic- to supralithostatic-fluid cycling. On the other hand, massive to laminated and fibrous veins indicate high-fluid pressures during vein formation. Large (up to $15-20 \mathrm{~cm}$ in length) euhedral to subhedral quartz crystals form coarse-crystalline aggregates in some veins.

The gold-quartz veins consist mainly of quartz, arsenopyrite, pyrite, and secondary haematite and limonite. Quartz is the most abundant mineral, typically comprising more than $90 \%$ of the veins. The other most abundant gangue minerals are calcite, muscovite/sericite, biotite, chlorite and epidote (Fig. 8). Haematite and limonite are dominant near the surface, whereas the arsenopyrite and pyrite contents of the veins increase with depth (Fig. 6F, G and Fig. 7). The proportion of sulfides is highly variable, from only traces to 3-4 volume percent of the veins. Other ore minerals detected include tennantite, stibnite, galena, sphalerite, chalcopyrite, pyrrhotite, molybdenite and gold. The quartz veins that cut the marble also contain scheelite.

Supergene minerals include limonite, haematite, malachite, azurite and covellite. Scarce gold occurs as isolated grains within quartz in limonite-haematite-rich veins near the surface, or as inclusions in sulfides in the deeper parts of the veins. The distribution of gold in the veins seems to be erratic, and only the limonite-rich parts of the veins near the surface consistently display higher gold contents - up to 16 ppm (H.Türkmen, pers. comm. 2004). The gold grade decreases downward. Although gold values are sporadically higher in the veins, trenching indicates average gold grades of approximately $1 \mathrm{~g} / \mathrm{t} \mathrm{Au}$. The gold distribution pattern in the veins indicates a close correlation with arsenic (Fig. 7).

\section{Alteration}

In the Savcılı area, host rocks display both supergene and hydrothermal alteration. The supergene alteration zones are characterised by their reddish brown colours (Fig. 6F) and by high limonite, haematite, kaolinitic clay and local gypsum content. Supergene alteration is restricted to the upper part of the quartz veins and to surrounding metamorphic rocks covered by Lutetian sediments (Figure 4). In the uncovered metamorphic rocks and quartz veins, supergene alteration is quite weak or absent. As a general trend, the intensity of alteration decreases from the contact with the Lutetian sediments at the top to the lower parts of the metamorphites and quartz veins.

Hydrothermal alteration is selectively vein-controlled and limited to the immediate vicinity of the quartz veins (Fig. 7). Alteration zones generally vary from a few $\mathrm{cm}$ to $2 \mathrm{~m}$ in width, with broader zones surrounding the thickest quartz veins. Within the same lithology, such as gneiss or schist, the alteration may be traced parallel to the quartz veins, both along strike and down dip, for tens of metres, showing little variation in mineralogy. The proximal alteration zone is characterised by the mineral assemblage quartz, biotite, albite, calcite, chlorite, sericite and/or muscovite, epidote, pyrite, arsenopyrite and pyrrhotite. 


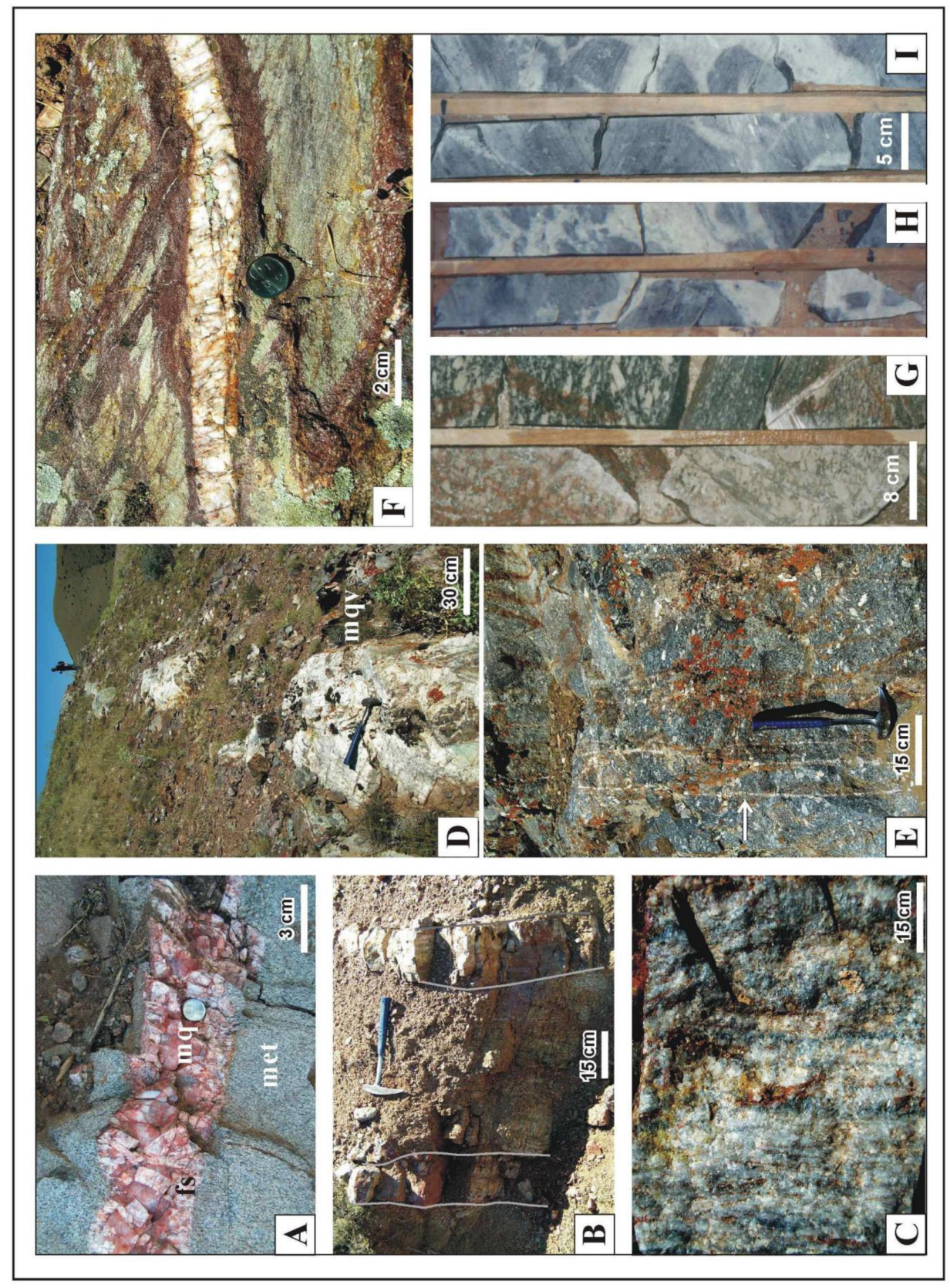

Figure 6. Photographs of gold-quartz veins and associated alteration in the Savcllebeyit area. A) Pegmatitic quartz veins, mq: massive quartz core, fs: feldspar-rich selvage, met: metatexitic host rock. B) Parallel quartz-, and haematite-limonite veins that cut the metatexitic migmatite. C) Banded quartz vein in outcrop. D) Massive quartz vein (mqv) that cuts the migmatitic gneiss. E) Parallel quartz veinlets that cut the metatexitic migmatite. F) Supergene alteration zones rich in haematite-limonite veins. G, H and I) Sections of drill core D-1 showing vein textures at different depths. G) 25.50-26.0m; metatexitic migmatites cut by quartz-pyrite veinlets. Hematitic staining on migmatites is common. H and I) Quartz breccia veins (white) with wall-rock fragments (gray) in mica gneiss. 115.5-116 $\mathrm{m}$ and 125-125.50 m.

Șekil 6. Savcılıebeyit alanındaki altınlı kuvars damarları ve bunlara bağlı alterasyonları gösteren fotoğraflar. A) Pegmatitik kuvars damarları, mq: masif kuvars; fs: feldspatça zengin kenar zonu; met: metateksitik yan kayaç. B) Metateksitik migmatiti kesen paralel kuvars ve hematit-limonit damarları. C) Bantı kuvars damar mostrası. D) Migmatitik gnaysı kesen masif kuvars damarı (mqv). E) Metateksitik migmatiti kesen paralel kuvars damarcıkları. F) Hematit-limonit damarları açısından zengin superjen alterasyon zonları. G, $H$ ve I) D-1 sondajı karotlarının değișik derinliklerinde gözlenen damar dokuları. G) 25.50-26.0 m; kuvars-pirit damarcıklarınca kesilmiș metateksitik migmatitler. Migmatitlerde hematit boyamaları yaygındır. $H$ ve I) Mika gnaysda breșik kuvars damarları (beyaz) ve yankayaç parçaları (gri). 115.5-116 ve 125-125.50 m. 


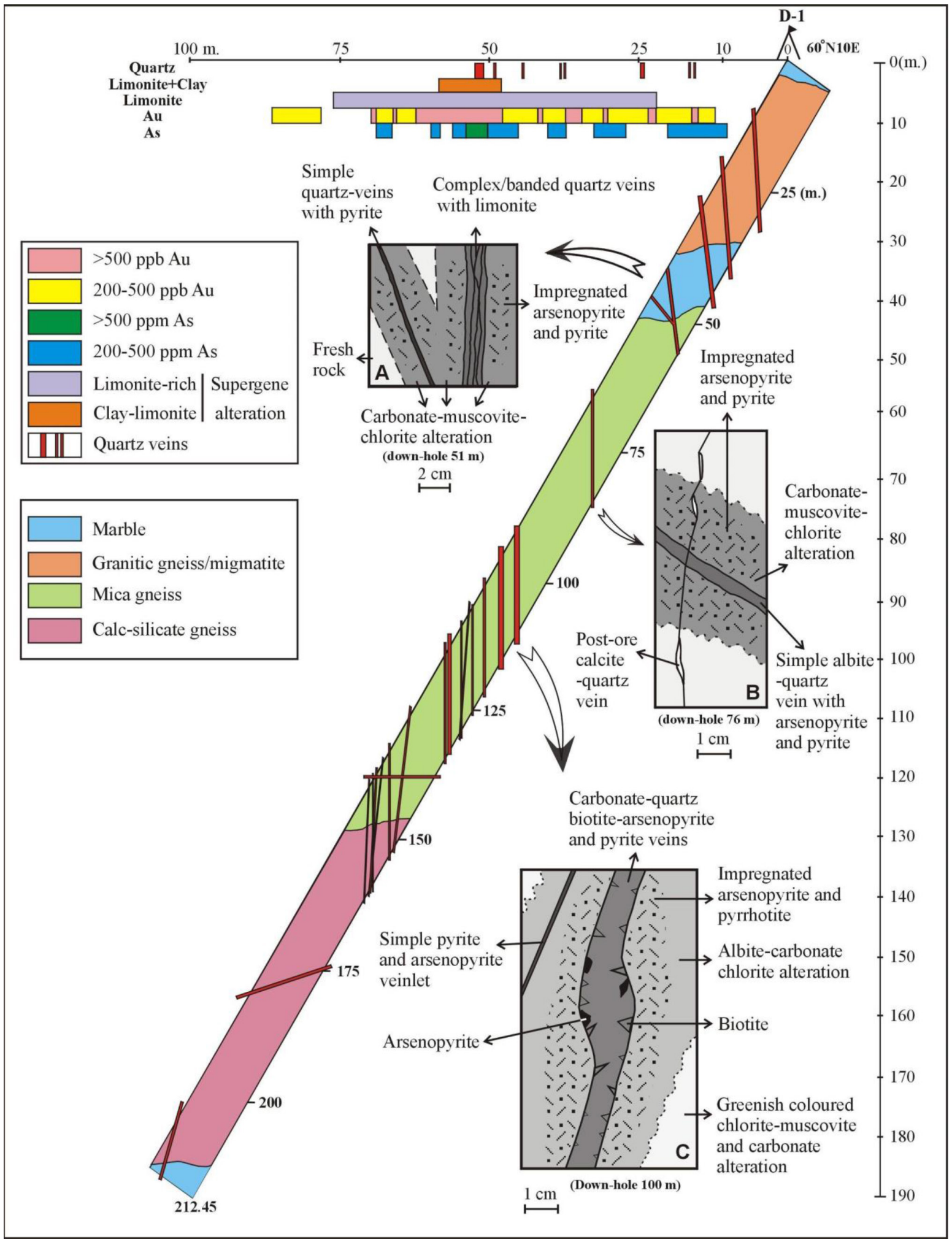

Figure 7. The distribution of gold-quartz veins that cut the metamorphic lithologies in drill core D-1. Data in the upper left side of the drill core is derived from surface trenches. The boxes lettered A, B and C show details from gold-quartz veins and surrounding alteration types detected in the drill core.

Șekil 7. D-1 sondaj karotlarında metamorfik birimleri kesen altınlı kuvars damarlarının dağılımları. Karotların üst sol tarafındaki veriler yüzeydeki hendeklerden elde edilmiștir. A, B ve C olarak isimlendirilmiș kutular karotlarda saptanmıș altınlı kuvars damarları ve bunlarla ilișkili bozunma türlerine ait ayrıntıları göstermektedir. 


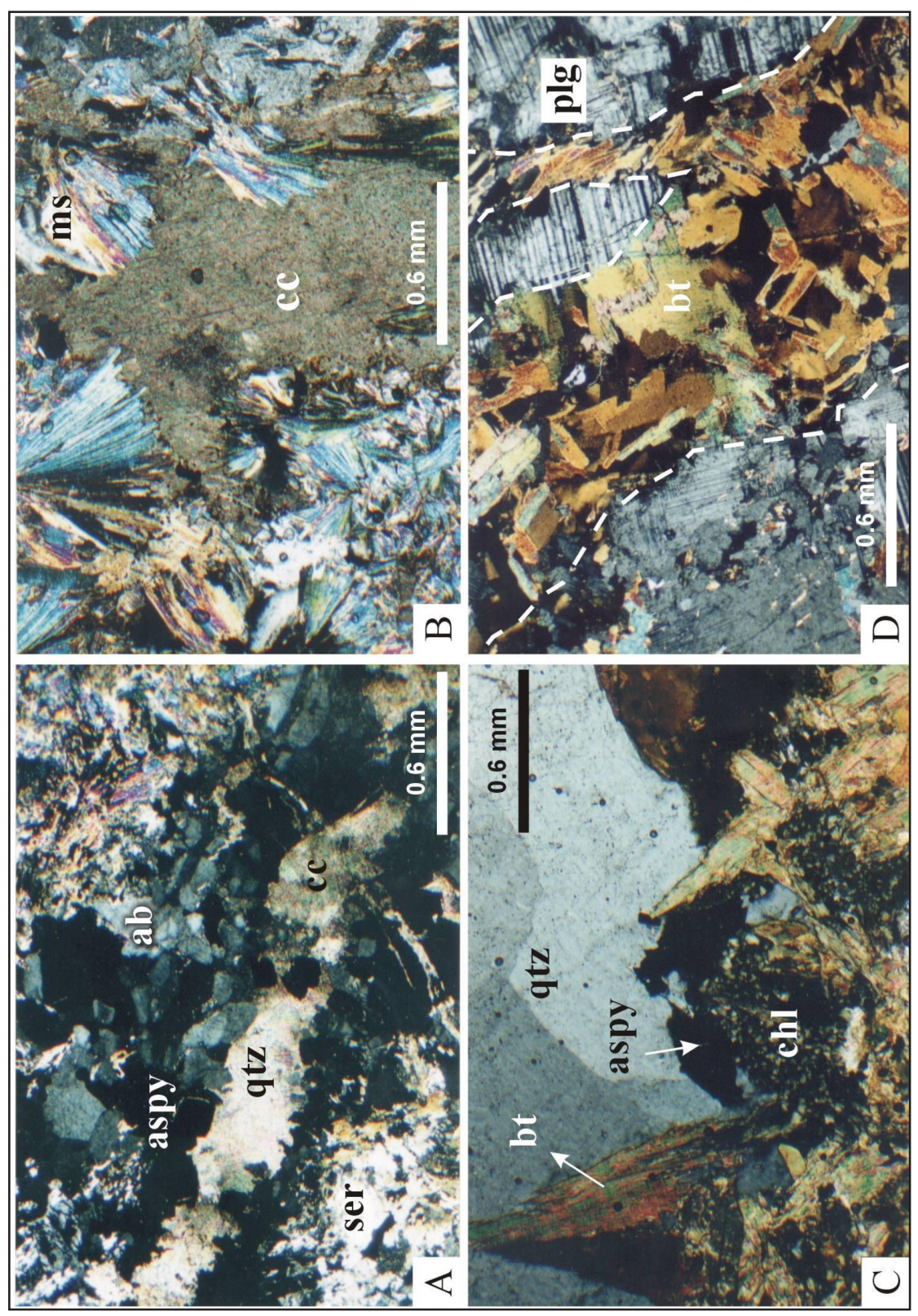

Figure 8. Gold-quartz veins and associated hydrothermal wall-rock alteration features in thin sections. A) Quartzcarbonate veins with albite and arsenopyrite selvages in intensely sericitised and chloritised migmatitic host rock, ab: albite; aspy: arsenopyrite; cc: calcite; qtz: quartz; ser: sericite (drill core D1, down-hole depth $76 \mathrm{~m}$ ); B) Pervasively carbonatised and sericitised migmatitic host rock, cc: calcite; ms: muscovite (drill core D1, down-hole depth $80 \mathrm{~m}$ ); C) Quartz-biotite-chlorite-arsenopyrite vein. The vein consists of a quartz core and biotite-chlorite and arsenopyrite selvages. Biotites grown from the wall towards the center of the vein, aspy: arsenopyrite; bt: biotite; chl: chlorite; qtz: quartz (drill core D1, down-hole depth $100 \mathrm{~m}$ ); D) Biotite vein that cuts plagioclases of amphibolite interlayers in mica gneiss, bt: biotite; plg: plagioclase (drill core D1, down-hole depth 140m).

Șekil 8. Altınlı kuvars damarları ve damarlara eșlik eden hidrotermal yan kayaç alterasyonlarının incekesit görünümleri. A) Yaygın olarak serizitleșmiș ve kloritleșmiș migmatitik yan kayaç içinde albit ve arsenopirit kenar zonlu kuvars-karbonat damarları. ab: albit; aspy: arsenopirit; cc: kalsit; qtz: kuvars; se: serizit (D-1 sondaj karotları, yüzeyden derinliği 76 metre); B) Yaygın olarak karbonatlașmıș ve serizitleșmiș migmatitik yan kayaç; cc: kalsit; ms: muskovit (D-1 sondaj karotları, yüzeyden derinliği 80 metre); C) Kuvars-biyotit-klorit-arsenopirit damarı. Damarın içi kuvars, kenarları biyotit-klorit ve arsenopiritten olușmuștur. Biyotitler damarın kenarından merkezine doğru büyümüșlerdir. aspy: arsenopirit; bt: biyotit; chl: klorit; qtz: kuvars ( $D$-1 sondaj karotları, yüzeyden derinliği 100 m); D) Mika gnaysın amfibolit katmanlarındaki plajiyoklazları kesen biyotit damarı; bt: biyotit; plg: plajiyoklaz. (D-1 sondaj karotları, yüzeyden derinliği 140 m). 
The distal alteration assemblage is chlorite, sericite and calcite. Boundaries between proximal and distal alteration zones may be sharp or gradational over centimetres to decimetres. The hydrothermal mineral assemblages vary with depth (Fig. 7). Proximal alteration in the upper part is marked by light white-yellow and brownish colours, indicating sericitisation and silicification. In the deeper part of the vein system, the main proximal alteration minerals are quartz, biotite, muscovite, albite, chlorite, calcite and epidote (Fig. 7, Fig. 8A, B, C and D). Quartz, biotite and albite occur as both veinlets and irregular aggregates in metamorphic rocks whereas muscovite, chlorite and calcite in distal alteration zones mainly replace feldspar in the wallrock and occur as aggregates (Fig. 8A, B). Proximal alteration haloes around quartz veins also contain disseminated arsenopyrite, pyrite and pyrrhotite (Fig. 7). The muscovite + albite paragenesis of the alteration zones suggests that the quartz veins have formed from fluids of approximately neutral pH (McCuaig and Kerric 1994). Opaque mineral assemblages within the quartz veins reflect greenschist- to amphibolite-facies conditions. According to McCuaig and Kerric (1994), the pyrite \pm arsenopyrite \pm stibnite \pm pyrrhotite paragenesis characterises subgreenschist- to low-amphibolite-facies conditions, whereas the loellingite \pm arsenopyrite \pm magnetite \pm ilmenite \pm pyrrhotite assemblage is typical of amphibolite-granulite-facies conditions. The variation of hydrothermal mineral assemblages with depth suggests changing pressure and temperature conditions with depth or lateral proximity to the granitic core of the granite-migmatite dome.

\section{Fluid inclusions}

Studies of fluid inclusions in quartz hosted by different types of veins revealed complex phase assemblages of the trapped fluids. Primary depositional features of the quartz are generally destroyed. They typically contain abundant secondary and pseudosecondary fluid inclusions along intergranular and transgranular fractures. Primary fluid inclusions show heterogeneous entrapment features. The same sample contains both vapour-rich and liquid-rich primary inclusions with very different liquid/vapour ratios. Their shapes are also highly variable; i.e., inclusions with regular forms are mostly liquid fluid-rich and coexist with more rounded gas-rich inclusions. The size of inclusions varies between $5 \mu \mathrm{m}$ and $70 \mu \mathrm{m}$. The homogenisation temperatures of the primary fluid inclusions from discordant quartz veins have a wide range $\left(160^{\circ} \mathrm{C}\right.$ to above $\left.400^{\circ} \mathrm{C}\right)$, whereas quartz samples from foliation-parallel veins give a slightly more restricted homogenisation temperature range, from $220^{\circ} \mathrm{C}$ to well above $400^{\circ} \mathrm{C}$. The fluid inclusions are generally rich in carbon dioxide and also have high salinities. The salinity of the studied fluid inclusions is between $20 \%$ and $33 \% \mathrm{NaCl}$ equivalent (SezererKuru and Genç 2003).

\section{Discussion and Conclusions}

Temporal relationships between vein formation and geological events

According to the geological and structural evidence presented here, the Savcllı gold-quartz veins are epigenetic and structurally controlled by E-W-trending vertical tensional fractures. The veins cut across all rock types except the Middle Eocene sediments. Pegmatitic quartz-feldspar veins and auriferous quartz veins formed at different structural levels and may have different ages of formation within the context of granite-migmatite doming. Pegmatitic barren quartz-feldspar veins are hosted by migmatite close to the granite core and are spatially related to aplite dykes. Gold-bearing quartz veins cut across the foliation and bedding of the schists and gneisses that were folded during the granite-migmatite doming. To the west, gold-quartz veins also cut progressively higher-grade rocks towards the migmatite core. This veining post-dates metamorphism and ductile deformations of Late Cretaceous age. Erkan and Ataman

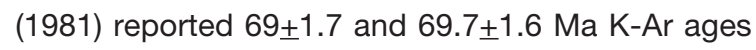
on biotite in metamorphic rocks of the Kırșehir region; these ages record the cooling of the metamorphic rocks to $<350^{\circ} \mathrm{C}$ and provide a minimum age for metamorphic deformation, and also a maximum age for brittle deformation and/or vein formation. The presence of blocks of quartz-vein material in the basal conglomerate of the Lutetian sediments suggests that the veins are older than Lutetian (40-46 Ma, ICS, 2004). These ages are also in agreement with fission-track ages (40 and $47 \mathrm{Ma}$ : Fayon et al. 1999) of the granites, which give the age of the granites' exhumation to near the surface. Thus, the hydrothermal event associated with mineralisation took place between Late Cretaceous (Maastrichtian) and Lutetian, during the latest, brittle stages of doming and exhumation of the metamorphic rocks of the Kırșehir Metamorphic Core Complex. This also suggests that gold-quartz veins were formed by a long- 
lived hydrothermal system of crustal scale. Without radiometric age data, it is not possible to give a better estimate for the duration of vein formation. Similar long-lived hydrothermal systems are also reported in the northwestern Alps and in the Variscan belt of Western Europe (Pettke et al. 1999 and 2000; Bouchot et al. 2000; Boiron et al. 2003). According to Pettke et al. (1999 and 2000), the ore-bearing fluid was produced by a 20 m.y. history of prograde metamorphic devolatilisation of calc-schists at depth. On the other hand, for the Variscan $\mathrm{Au}, \mathrm{Sb}, \mathrm{W}$ orogenic deposits in the French Massif Central, Bouchot et al. (2000) and Bellot et al. (2003) gave a duration of $5 \mathrm{Ma}$ for the Au-W-Sb "metalliferous peak".

\section{Conditions of gold-quartz vein formation}

Sharp contacts with host rocks and the small extent of metasomatism in the wall rocks indicate that fluid/ rock ratio was low during vein formation, and fluids appear to have migrated slowly. The banded and brecciated nature of some quartz veins suggests multiple fluid events. On the other hand, alteration mineral parageneses reveal that quartz veins have formed at different structural levels and pressuretemperature conditions. According to McCuaig and Kerric (1994), in granitoid host rocks, the quartzalbite-muscovite-chlorite paragenesis characterises sub- to mid-greenschist-facies conditions and shallower formation depths $\left(225-400^{\circ} \mathrm{C},<1-3 \mathrm{kbar}\right.$ and $<5$ to $10 \mathrm{~km}$ ), whereas the occurrence of biotite in the paragenesis indicates higher pressure-temperature and depth conditions $\left(375-550^{\circ} \mathrm{C}, 2\right.$ - 4 kbar, 7 - 14 $\mathrm{km}$, greenschist-amphibolite transition). Mono- or bimineralic alteration selvages (Fig. $8 \mathrm{~A}, \mathrm{C}$ ) adjacent to the veins are indicative of formation within an open hydrothermal system. Homogenisation temperatures of fluid inclusions give a wide temperature of formation range, from $160^{\circ} \mathrm{C}$ to well above $400^{\circ} \mathrm{C}$ for quartz veins. Based on fluid- inclusion data, these temperature conditions - which are lower than those of the amphibolite facies - appear to have developed during the last stages of doming or the waning stages of regional metamorphism. Discordant quartz veins in the migmatite and gneiss units suggest that vein emplacement must have taken place under retrograde, brittle conditions in a near-surface environment above the brittle-ductile transition zone. Such a situation is possible after shallowing of the highgrade metamorphic rocks and migmatites through migmatite doming and/or post-orogenic granitoid emplacement, during brittle fracturing at shallow crustal depths (Fig. 9).

According to structural and petrographic data given in this study, the initiation of granite-migmatite doming was synchronous with low pressure-high temperature metamorphism in the region. The age of metamorphism in the Kırșehir Massif is interpreted from K/Ar biotite and hornblende ages to have been between $69.7 \pm 1.6$ and $74.2 \pm 2.7 \mathrm{Ma}$ (Erkan and Ataman 1981). These data were interpreted by those authors as the emplacement and cooling ages of the granitoids. Similarly, in the Niğde region, exhumation of sillimanite-zone metamorphic rocks and plutons to shallower depths (<12 km) occurred between 78 to $74 \mathrm{Ma}$ (Whitney et al. 2003). Ascent and emplacement of the granitoid-migmatite dome may have developed partly through ductile remobilization of the migmatitic lower part of the metamorphic pile and partly through emplacement of successive generations of hornblende granite and microgranite derived by melting of the lower crust (Fig. 9A, B). Blocks of high-grade metamorphic rocks and deformation structures within metatexite, and the orientation of enclaves parallel to the general flow structure within diatexite, apparently represent a flow pattern due to upward migration of the migmatites (Figs.5 and 10). Migmatites may have formed at different depths. Under normal geothermal gradients $\left(30-40^{\circ} \mathrm{C} / \mathrm{km}\right)$, migmatite formation can occur at depths of about 15 - $25 \mathrm{~km}$. During metamorphism, the geothermal gradient, however, may be higher than normal (50 - $150^{\circ} \mathrm{C} / \mathrm{km}$ ), and migmatite formation can occur at about 4 - $10 \mathrm{~km}$ below the surface (Mehnert, 1968). High-grade metamorphic rocks and granitoids imply a high thermal gradient in the Kırșehir region. Accordingly, migmatitisation in the Savcllebeyit area may have occurred at shallower depths - at less than $10 \mathrm{~km}$. Active shallow Curie point depths $(8-10 \mathrm{~km})$ in central Anatolia (Genç and Yürür 2010) also support this conclusion. The cause of the asymmetry and southeastward tilting of the dome may have been due to movements on the Kaman detachment fault. Tilting of the dome may have been responsible for the southeastward overturning of the metamorphic sequence and the opening of tension fractures later filled by gold-quartz veins (Fig. 9B, C).

\section{The origin of fluids}

The origin of the fluids responsible for the formation of gold-quartz veins in high-grade metamorphic rocks has long been debated. Different sources have 


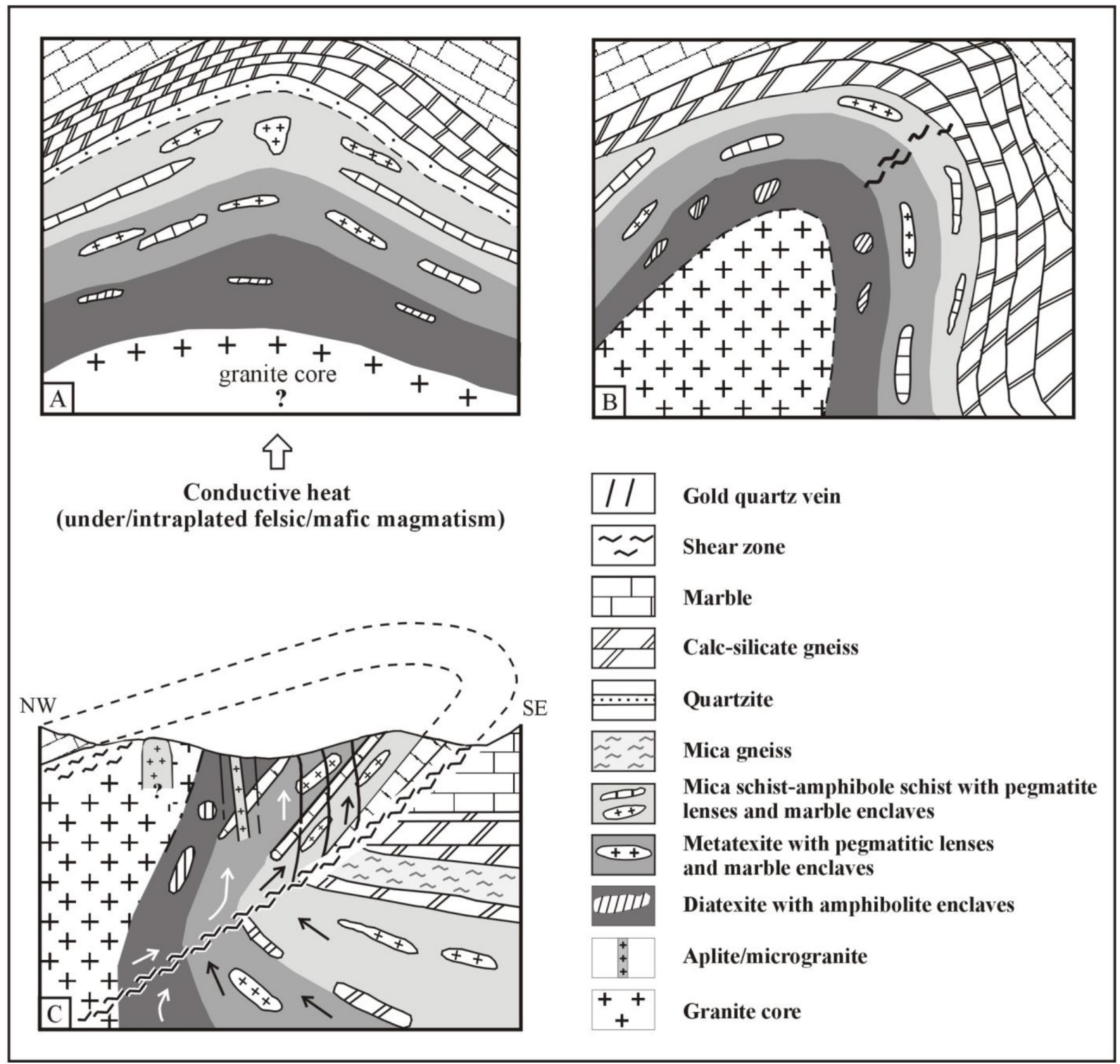

Figure 9. A schematized scenario (not to scale) for the evolution of granite-migmatite doming and quartz veining in the Savclliebeyit area. A) Prograde metamorphism and partial melting of the lower part of the metamorphic sequence by heat input during late Cretaceous underplating felsic/mafic magmatism. B) Widespread partial melting triggered the ascent of the granite-migmatite dome. C) Tilting and emplacement of the dome, formation of tension fractures in the upper part of the dome and filling of these fractures later with gold-quartz veins.

Șekil 9. Savcılıebeyit alanındaki granit-migmatit domu ve kuvars damarlarının olușumunun evrimini gösteren ölçeksiz șematik senaryo. A) ilerleyen metamorfizma ve Geç Kretase'de felsik/mafik magmatizmadan gelen Isı ile metamorfik istifin alt kesiminin kısmi ergimesi. B) Granit-migmatit domunun yükselmesini tetikleyen geniș yayılımlı kısmi ergime. C) Domun eğim kazanması ve yerleșmesi, domun üst kısmında açılma çatlaklarının olușumu ve daha sonra bu çatlakların altınlı kuvars damarlari ile dolması.

been proposed for the fluids, such as magmatic, metamorphic and upper-mantle degassing, and/or lower crust granulitisation (Bennett and Barker 1992; Yardley and Bottrel 1992; Groves 1993; Munz et al. 1995; Robert 1995; Boiron et al. 1996; Bierlein et al. 1998; Goldfarb et al. 1998; Stüve 1998; Eilu et al. 1999; Gleeson et al. 2003; Groves et al. 2003). For some regions, the role of meteoric waters penetrating to deeper parts of the crust through detachment faults has also been considered important (Munz et 


\section{al. 1995; Robert 1995).}

For the Savcıliebeyit area, the origin of the goldquartz vein-forming fluids is as yet uncertain. The close temporal and spatial association of migmatite and post-orogenic granitoids with gold-quartz veins suggests that fluids may have been both of magmatic or metamorphic origin. However, in the literature, highly saline and $\mathrm{CO}_{2}$-rich fluid inclusions characteristic of the Savcılı area are generally accepted as a sign of mantle degassing or lower-crust granulitisation (Fyon et al. 1984; Cameron 1988). Alternatively, saline- $\mathrm{H}_{2} \mathrm{O}$ fluids are accepted as representing saline brines that have, through time, percolated down through metamorphic rocks, or as deeply sourced fluids that were trapped during post-peak metamorphism (Guha and Kanwar 1987; Bennett and Barker 1992; Hagemann and Ridley 1993).

Moderately to highly saline ore-forming brines are also detected in iron-oxide copper (gold) deposits (Hitzman 2000; Pollard 2000 and 2001). However, these deposits display extensive sodic alteration, comprising albite, magnetite, chlorite, or actinolite, usually associated with scapolite, haematite, epidote, calcite and titanite (Haynes 2000). Neither alteration types nor ore-mineral content of the Savcılı gold-quartz veins are similar to those of iron-oxide copper (gold) systems. The cause of the high salinity of ore-forming fluids in the Savcılı area could be metaevaporitic intercalations within calc-silicate gneisses, surface saline-water sources, or interaction of hydrothermal fluids with anhydrous rocks. The existence of metaevaporitic intercalations within the Kırșehir massif was reported by Genç (2001). On the other hand, recent deep drilling and isotope studies have documented the presence of highly saline fluids (up to $40 \mathrm{wt} \% \mathrm{NaCl}$ equivalent) in basement rocks at depths of up to $10 \mathrm{~km}$ (Möller et al. 1997; Smith et al.1998; Stober and Bucher 1999; Gleeson et al. 2003). In accordance with this documentation, Mullis et al. (1994) reported $\mathrm{CO}_{2}$-rich continental fluids from the Central Alps and concluded that the $\mathrm{CO}_{2}$ component was derived from the oxidation of graphitic matter - especially in the vicinity of sulfatebearing metasediments - and from decarbonation reactions.

Observations of drill cores reveal that, in the deeper part of the section at Savcılıebeyit, wollastonite-rich calc-silicate gneisses are abundant. According to Bucher and Frey (1994), wollastonite-rich rocks do not form in regional metamorphic settings under closed-system conditions; they may only form by interaction of a carbonate-rich source rock with a foreign, externally derived $\mathrm{H}_{2} \mathrm{O}$-rich fluid. These fluids may be released during partial melting of pelitic rocks lying in the deeper part of the metamorphic pile. Under these conditions, calcite and quartz may react and produce wollastonite and release $\mathrm{CO}_{2}$ gas. This consideration suggests that $\mathrm{CO}_{2}$-rich fluid inclusions in the Savcllebeyit quartz veins were mainly metamorphic in origin. A similar conclusion is given by Pettke et al. (1999 and 2000) for the northwestern Alps. According to those authors, metamorphic devolatilisation of Mesozoic calc-schists is the main source of ore-forming fluids. This conclusion further suggests that higher temperature conditions in the deeper part of the crust caused partial melting and released metamorphic fluids, while metamorphic rocks exhumed to shallower levels are on their retrograde path. These fluids precipitated the postmetamorphic gold-quartz veins in the cooling rocks. Heterogeneous entrapment features, such as the presence of liquid-rich inclusions in addition to inclusions having highly variable liquid/vapour ratios, and vapour-rich inclusions in the same sample, and the wide range of homogenisation temperatures of the fluid inclusions, suggest that mixing of hot metamorphic fluids with cold, surface-derived, oxidised waters is also an important factor for gold enrichment in the quartz veins.

Consistently higher gold contents of veins near the surface may be explained through secondary enrichments caused by supergene alteration. The spatial and temporal distribution of supergene alteration zones and the absence of abundant hydrothermal quartz within the secondary alteration suggest that oxidising, limonite- and haematite-forming fluids in the Savcılı area did flow downward. The invoked fluid source is the overlying Lutetian sediments. These fluids have used the preexisting fractures and surfaces, hence, mostly affected the upper part of the quartz veins and surrounding host rocks.

In conclusion, Savcilı gold-quartz veins have many similarities to orogenic gold deposits of the Alpine and Variscan collisional belts in terms of metal associations, wall-rock alteration assemblages, mineralogy, formation conditions and structural control. The known Sb-Hg-W ( $\pm \mathrm{Au}$ ) deposits of the Niğde region and the newly discovered gold mineralizations of the Kırșehir, Kayseri and Nevșehir regions suggest that the extensional tectonics and granite-migmatite 
dome structures of central Anatolia constitute a favorable geological environment for orogenic gold deposits. The existence of gold deposits in similar metamorphic and tectonic environments of the $\mathrm{Al}$ pine and Variscan belts indicates that future discoveries in central Anatolia are likely to be of economic significance. Further field investigations are necessary to better understand the extent and mode of formation of these gold enrichments.

\section{Acknowledgements}

The field work for this study would not have been possible without the assistance of Halil Türkmen and generous support from the Mineral Research and Exploration Institute of Turkey (MTA). This research was supported by Research Funds of the Hacettepe University (Project no: 0601602004). We are thankful to reviewers Dr. Ahmet GÖKÇE and Dr. Mehmet SSENER for their constructive remarks to improve the manuscript.

\section{REFERENCES}

Akçay M., 1994. Genesis of the stibnite-cinnabarscheelite deposits of the Gümüșler area, Niğde, central Turkey and implications for their gold potential. Ph.D thesis, University of Leicester, 241pp. (unpublished).

Ataman G. 1972. Etude préliminaire sur l'âge radiométrique de Cefalıkdağ massif, I'un des massifs granitique-granodioritique au sud-est d'Ankara. Hacettepe Fen ve Mühendislik Bilimleri Dergisi 2(1): 44-49 (in Turkish with French abstract).

Aydın SN. and Önen AP., 1999. Field, petrographic and geochemical features of the Baranadağ quartz monzonite of the Central Anatolian Granitoids, Turkey. Turk. J. Earth Sci. 8: 113-123.

Ayan M., 1963. Contribution à l'étude petrographique et géologique de la region située au NordEst de Kaman. MTA publ. 115: 332 pp.

Bellot JP, Lerouge C, Bailly L and Bouchot V., 2003. The Biards Sb-Au-bearing shear zone (Massif Central, France): an indicator of crustalscale transcurrent tectonic guiding Late Variscan collapse. Economic Geology 98: 1427-1447.
Bennett DG and Barker AJ., 1992. High salinity fluids: The results of retrograde metamorphism in thrust zones. Geochimica et Cosmochimica Acta 56: 81-95.

Bierlein FP, Fuller T, Stüwe K, Arne DC and Keays RR., 1998. Wallrock alteration associated with turbidite-hosted gold deposits. Examples from the Palaeozoic Lachlan Fold Belt in central Victoria, Australia. Ore Geology Reviews 13: 345-380.

Boiron MC, Cathelineau M, Banks DA, Yardley BWD, Noronha F, Miller FM., 1996. P-T-X conditions of late Hercynian fluid penetration and the origin of granite-hosted gold quartz veins in northwestern Iberia: A multidisciplinary study of fluid inclusions and their chemistry. Geochimica et Cosmochimica Acta 60: 43-57.

Boiron MC., Cathelineau M., Banks DA., Fourcade S., Vallance J., 2003. Mixing of metamorphic and surficial fluids during the uplift of the Hercynian upper crust: consequences for gold deposition. Chemical Geology 194: 119-141.

Bouchot V, Milesi JP and Ledru P., 2000. Crustalscale hydrothermal palaeofield and related variscan $\mathrm{Au}, \mathrm{Sb}, \mathrm{W}$ orogenic deposits at 310-305 Ma (French Massif Central, Variscan Belt). SGA News 10: 1-12.

Brinkmann R., 1971. Das kristalline Grundgebirge von Anatolien. Geologische Rundschau 60: 886-899.

Brinkmann R., 1976. Geology of Turkey. Elsevier, Amsterdam, $158 \mathrm{pp}$.

Bucher K and Frey M., 1994. Petrogenesis of metamorphic rocks. Springer, Heidelberg, 318 pp.

Cameron EM., 1988. Archean gold: Relation to granulite formation and redox zoning in the crust. Geology 16: 109-112.

Coșkun Delibaș E and Genç Y., 2004. Terziali-Çayağzı (Kırșehir) gold mineralization: initial findings of saprolitic gold enrichments in Kırșehir Massif. Yerbilimleri 30: 23-33 (in Turkish with English abstract).

Eilu PK, Mathison $\mathrm{Cl}$, Groves DI and Allardyce WJ., 1999. Atlas of alteration assemblages, styles and zoning in orogenic lode-gold deposits in a variety of host rock and metamorphic 
setting, Geology and Geophysics Department (Centre for Strategic Mineral Deposits) and UWA Extension, The University of Western Australia Publication 30: 50pp.

Erkan Y., 1976. Isograds determined in the regional metamorphic area surrounding Kırșehir and their petrological interpretation. Yerbilimleri 2(1): 23-54 (in Turkish with English abstract).

Erkan Y., 1980. A study on regional metamorphism of northeastern part of Central Anatolian Massif (Akdağmadeni, Yozgat). Bulletin of the Geological Society of Turkey 23: 213-218 (in Turkish with English abstract).

Erkan $Y$ and Ataman G., 1981. A study on the age of metamorphism of Central Anatolian Massif (Kırșehir region) by K-Ar method. Yerbilimleri 8: 27-30 (in Turkish with English abstract).

Fayon AK, Whitney DL and Dilek Y., 1999. Constraints on the transition from Alpine crustal thickening to extension in central Anatolia. EOS 80, 1066.

Fyon JA, Crocket JH and Schwarcz HP., 1984. The Carshaw and Malga iron-formation- hosted gold deposits of the Timmins area. In: Colvine AC (ed.) The Geology of Gold in Ontario. Ontario Geological Survey Miscellaneous Paper 110: 98-110.

Genç Y., 2001. The metamorphic textures and structures in the Bașçatak (Akdağmadeni-Yozgat) Zn-Pb-Cu sulphide deposit, 54th Geological Congress of Turkey, Proceedings CD, 54-51 (in Turkish with English abstract).

Genç $Y$ and Türkmen H., 2002. Gold-quartz veins in Kırșehir Metamorphic Massif, 55th Geological Congress of Turkey, Abstracts Book, 102-103.

Genç Y., 2003. New observations on the metamorphic stratigraphy of the Kırșehir Massif, 56th Geological Congress of Turkey, Extended Abstracts Book, 55-56.

Genç Y, Türkmen H, Coșkun E, Çamașırcıoğlu A, Aydınlı I and Demiray B., 2003. Çayağzı-Terziali (Kırșehir) gold mineralization: the first example of unconformity-related gold mineralisations in the Kırșehir Metamorphic Massif, 56th Geological Congress of Turkey, Extended Abstracts Book, 120-121.

Genç Y, Vennemann TW and Satir M., 2003a. Carbon, oxygen and hydrogen isotope evidence for the origin of the sediment hosted Pöhrenk (Çiçekdağı-Kırșehir-central Anatolia) fluorite deposit, Turkey. In: Eliopoulos et al (eds), Mineral Exploration and Sustainable Development, Proceedings vol. 2: 871-874. 7th Biennial SGA Meeting, Athens, Greece, 2428 August 2003.

Genç Y., 2004. Savcılı migmatite-dome hosted goldquartz veins in Kırșehir Metamorphic Core Complex (KMCC), central Anatolia, Turkey. In: Chatzipetros AA and Pavlides SB (eds.), Proceedings vol. 3: 1394-1397. 5th International Symposium on Eastern Mediterranean Geology, Thessaloniki, Greece, 14-20 April 2004.

Genç $Y$ and Yürür T., 2004. The Kırșehir detachment faulting and a new interpretation of the "Savcılı Thrust Zone" in central Anatolia, Turkey. In: Chatzipetros AA and Pavlides SB (eds.) Proceedings, vol. 1: 73-76. 5th International Symposium on Eastern Mediterranean Geology, Thessaloniki, Greece, 14-20 April 2004.

Genç $Y$ and Yürür T., 2010. Coeval extension and compression in Late Mesozoic-Recent thinskinned extensional tectonics in central Anatolia, Turkey. Journal of Structural Geology 32 (5), 623-640.

Geven A., 1992. Mineralogy, Petrography and Geochemistry of Cefalıkdağ Plutonic Rocks (Kaman region-Central Anatolia). Ph.D. thesis, Middle East Technical University, 165 pp. (unpublished).

Gleeson SA, Yardley BWD, Munz IA and Boyle AJ., 2003. Infiltration of basinal fluids into highgrade basement, south Norway: sources and behaviour of waters and brines, Geofluids 3: 33-48.

Goldfarb RJ, Phillips GN and Nokleberg WJ ., 1998. Tectonic setting of synorogenic gold deposits of the Pacific Rim, Ore Geology Reviews 13: 185-218.

Göncüoğlu MC., 1986. Geochronological age data from the southern part of the central Anatolia Massif. Bulletin of Mineral Research and Exploration Institute of Turkey 105/106: 111-124 (in Turkish).

Göncüoğlu MC, Toprak V, Kușçu İ, Erler A and Olgun E ., 1991. The geology of the western part of 
the central Anatolia Massif, chapter 1: Southern part. National Oil and Gas Company of Turkey, Report No: 2909, 140pp (in Turkish with English abstract).

Groves DI., 1993. The crustal continuum model for late-Archean lode gold deposits of the Yilgarn Block, Western Australia. Mineralium Deposita 28: 366-374.

Groves DI, Goldfarb RJ, Gebre-Mariam M, Hagemann SG and Robert F., 1998. Orogenic gold deposits: A proposed classification in the context of their crustal distribution and relationship to other gold deposit types. Ore Geology Reviews 13: 7-27.

Groves DI, Goldfarb RJ, Robert F and Hart CJR., 2003. Gold deposits in metamorphic belts: overview of current understanding, outstanding problems, future research, and exploration significance. Economic Geology 98: 1-29.

Guha J and Kanwar R., 1987. Vug brines - fluid inclusions: a key to understanding of secondary gold enrichment processes and the evolution of deep brines in the Canadian Shield. In: Fritz P and Frape SK (eds) Saline Water and Gases in the Crystalline Rocks. Geological Association of Canada Special Paper 33: 95-101.

Haynes DW., 2000. Iron Oxide Copper (-Gold) Deposits: Their Position in the Ore Deposit Spectrum and Modes of Origin. In: Porter TM (ed.) Hydrothermal Iron Oxide Copper-Gold and Related Deposits: A Global Perspective, Australian Mineral Foundation, Adelaide, 71-90.

Hagemann SG and Ridley JR., 1993. Hydrothermal fluids in epi- and katazonal crustal levels in the Archean: implications for P-T-X-t evolution of lode-gold mineralisation. In: Williams PR and Haldane JA (eds) Kalgoorlie '93: An International Conference on Crustal Evolution, Metallogeny and Exploration of the Eastern Goldfields: Australian Geological Survey Organisation, Record 1993/54: 123-130.

Hitzman MW., 2000. Iron oxide-Cu-Au deposits: what, where, when, and why. In: Porter TM (ed.) Hydrothermal Iron Oxide Copper-Gold and Related Deposits: A Global Perspecti- ve. Australian Mineral Foundation, Adelaide: 9-25

ICS., 2004. International Commission on Stratigraphy: 2004: International Stratigraphic Chart.

Ilbeyli N, Pearce JA, Thirlwall MF and Mitchell JG., 2004. Petrogenesis of collision-related plutonics in central Anatolia, Turkey. Lithos 72(3-4): 163-182.

Kadıoğlu YK., Dilek Y., Güleç N. and Foland KA., 2003. Tectonomagmatic evolution of bimodal plutons in the Central Anatolian Crystalline Complex, Turkey. Journal of Geology 111: 671-690.

Ketin I., 1955) On the geology of Yozgat region and the tectonic features of the Central Anatolian Massif (Kırșehir Crystallines). Bulletin of the Geological Society of Turkey VI (1): 1-20 (in Turkish with English abstract).

Ketin I., 1966. Tectonic units of Anatolia (Asia Minor). Bulletin of the Mineral Research and Exploration Institute of Turkey 66 (foreign edition): 23-34.

McCuaig TC. and Kerric R., 1994. P-T-t deformation-fluid characteristics of lode gold deposits: Evidence from alteration systematics. In: Lentz DR (ed.) Alteration and Alteration Processes associated with Ore-Forming Systems. Geological Association of Canada, Short Course Notes 11: 339-379.

Mehnert KR., 1968. Migmatites and the origin of granitic rocks. Elsevier, New York, 393pp.

Möller P, Weise SM, Althaus E, Bach W, Behr HJ, Borchardt R, Bräuer K, Drescher J, Erzinger J, Faber E, Hansen BT, Horn EE, Heunges E, Kämpf H, Kessels W, Kirsten T, Landwehr D, Lodemann M, Machon L, Pekdeğer A, Pielow H-U, Reutel C, Simon K, Walther J, Winlich FH, Zimmer M., 1997. Paleofluids and recent fluids in the upper continental crust: results from the German Continental Deep Drilling Program (KTB). Journal of Geophysical Research 102, B18233-18254.

MTA., 2002. Geological maps of Turkey, 1/500,000 scale, Ankara sheet, MTA (General Directorate of Mineral Research and Exploration), Ankara.

Mullis J, Dubessy J, Poty B, and O’Neil J ., 1994. Fluid regimes during late stages of continental collision: Physical, chemical, and stable 
isotope measurements of fluid inclusions in fissure quartz from a geotraverse through the Central Alps, Switzerland. Geochemica et Cosmochimica Acta 58/10, 2239-2267.

Munz IA, Yardley BWD, Banks DA and Wayne D., 1995. Deep penetration of sedimentary fluids in basement rocks from southern Norway: evidence from hydrocarbon and brine inclusions in quarz veins. Geochimica et Cosmochimica Acta 59(2): 239-254.

Özcan A. and Çağatay MN., 1989. Tungsten exploration in semiarid environment: Central Anatolian Massif, Turkey. Journal of Geochemical Exploration 31, 185-199.

Özer S. and Göncüoğlu MC., 1983. Interesting mineral parageneses from the eastern part (Akdağmadeni-Yıldızeli) of the Central Anatolian Massif. Bulletin of Mineral Research and Exploration Institute of Turkey 95/96: 173174 (in Turkish).

Pehlivan AN. and Alpan T., 1986. The preliminary report on gold, tin and heavy mineral explorations in Niğde Massif. MTA report, Ankara (in Turkish).

Pettke T., Diamond LW. and Villa IM., 1999. Mesothermal gold veins and metamorphic devolatilization in the NW Alps: the temporal link. Geology 27: 641-644.

Pettke T., Diamond LW. and Kramers JD., 2000. Mesothermal gold lodes in the north-western Alps: a review of genetic constraints from radiogenic isotopes. Eur. J. Mineral. 12: 213-230.

Pollak A., 1958. Über einige geologische Beobachtungen im zentral-anatolischen Massiv. Notizbl. Hess. Landesamt Bodenforschung 87: 239-245.

Pollard PJ., 2000. Evidence of a magmatic fluid and metal source for Fe-oxide $\mathrm{Cu}$-Au mineralization. In: Porter TM (ed.) Hydrothermal Iron Oxide Copper-Gold and Related Deposits: a Global Perspective. Australian Mineral Foundation, Adelaide: 27-41

Pollard PJ., 2001. Sodic (-calcic) alteration in Feoxide-Cu-Au districts: an origin via unmixing of magmatic $\mathrm{H}_{2} \mathrm{O}-\mathrm{CO}_{2}-\mathrm{NaCl} \pm \mathrm{CaCl}_{2}-$ $\mathrm{KCl}$ fluids. Mineralium Deposita 36: 93-100.

Robert ., 1995) Gold-quartz veins in metamorphic terranes and their bearing on the role of fluids in faulting. Journal of Geophysical Research 100-B7: 12861-12879.

Seymen I., 1981. Stratigraphy and metamorphism of the Kırșehir Massif around Kaman (KırșehirTurkey). Geological Society of Turkey Bulletin 24(2): 101-108 (in Turkish with English abstract).

Seymen., 1982. Geology of Kırșehir Massif around Kaman. ITU Min.Fac. Istanbul, 164pp. (unpublished Thesis, in Turkish with English abstract).

Seymen I., 1984. Geological evolution of the metamorphic rocks in the Kırșehir Massif. Türkiye Jeoloji Kurumu, Ketin Symposium Book, 133-148 (in Turkish with English abstract).

Seymen I., 2000. Geology of the Kırșehir Massif between Savcılıebeyit (Kaman) and Yeșilli (Kırșehir) villages. Cumhuriyetin 75. Yıldönümü Yerbilimleri ve Madencilik Kongresi, Bildiriler Kitabı I, MTA-Ankara, 67-91 (in Turkish with English abstract).

Sezerer-Kuru G. and Genç Y., 2003. Fluid inclusion studies in the gold bearing quartz veins in Savcılıebeyit (Kaman-Kırșehir) Region. 56 ${ }^{\text {th }}$ Geological Congress of Turkey, Extended Abstract Book, pp 92.

Smith MP., Savary V., Yardley BWD., Valley JW., Royer JJ. and Dubois M ., 1998. The evolution of the deep flow regime at Soultzsous-Forêts, Rhine Graben, Eastern France: evidence from a composite quartz vein. Journal of Geophysical Research 103, 2722327237.

Stober I. and Bucher K ., 1999. Deep groundwater in the crystalline basement of the Black Forest region. Applied Geochemistry 14, 237-254.

Stüwe K ., 1998. Tectonic constraints on the timing relationships of metamorphism, fluid production and gold-bearing quartz vein emplacement. Ore Geology Reviews 13: 219228.

Tolluoğlu Ü., 1986. Petrographical and petrotectonic investigations in the southwestern part of the Central Anatolia Massif, Kırșehir region. Ph.D. thesis, Hacettepe University, Ankara. 237pp. (in Turkish with English abstract, unpublished).

Tolluoğlu Ü. and Erkan Y., 1989. Regional progressive metamorphism in the central Anatolian 
crystalline basement, NW Kırșehir Massif, Turkey. METU Journal of Pure and Applied Sciences 22(3): 19-41.

Tülümen E., 1980. The petrographic and metallogenic investigation of the Akdağmadeni region. Ph.D thesis, Karadeniz Technical University, 157pp (in Turkish with English abstract, unpublished).

Türkmen H., Demiray B., Karabalık N., Konya S., Yüce N., Çamașırcıoğlu A. and Bilgin R., 2000. Geological map of the Savciliebeyit gold mineralisation (unpublished data), MTA, Ankara.

Whitney DL. and Dilek Y., 1998. Metamorphism during Alpine crustal thickening and extension in central Anatolia, Turkey: the Niğde metamorphic core complex. Journal of Petrology 39(70): 1385-1403.
Whitney DL., Teyssier C., Dilek Y. and Fayon AK., 2001. Metamorphism of the Central Anatolian Crystalline complex, Turkey: influence of orogen-normal collision vs. wrenchdominated tectonics on P-T-t paths. Journal of Metamorphic Geology 19: 411-432.

Whitney DL., Teyssier C., Fayon AK., Hamilton MA. and Heizler M., 2003. Tectonic controls on metamorphism, partial melting, and intrusion: timing and duration of regional metamorphism and magmatism in the Niğde Massif, Turkey. Tectonophysics 376: 37-60.

Yardley BWD. and Bottrell SH., 1992. Silica mobility and fluid movement during metamorphism of the Connemara schists, Ireland. Journal of Metamorphic Geology 10: 453-464. 